\title{
PENGEMBANGAN POTENSI OLAHRAGA REKREASI PASER (TAHAP AWAL) SEBAGAI DAYA TARIK BARU DI OBJEK WISATA WADUK CACABAN KABUPATEN TEGAL
}

\author{
Dzulfikri Ritonga ${ }^{1}$, Mohammad Arif $\mathrm{Ali}^{2}$, Abadi Pitojo ${ }^{3}$, Nanang Indardi ${ }^{4}$, Gustiana Mega Anggita ${ }^{5}$, \\ Nur Hadziq Haidar ${ }^{6}$, Afan Afghani ${ }^{7}$
}

\begin{abstract}
Jurusan Ilmu Keolahragaan Fakultas Ilmu Keolahragaan Universitas Negeri Semarang ${ }^{1}$ Dinas Pemuda Olahraga dan Pariwisata Kabupaten Tegal ${ }^{2}$

afanafghani@students.unnes.ac.id
\end{abstract}

\begin{abstract}
ABSTRAK
Objek Wisata Waduk Cacaban memiliki potensi yang dapat dikembangkan, kurangnya minat pengunjung Waduk Cacaban menjadi permasalahan utama. Tujuan penelitian ini untuk mengembangkan potensi olahraga rekreasi Paser sebagai daya tarik baru di Objek Wisata Waduk Cacaban untuk meningkatkan minat pengunjung. Penelitian ini menggunakan metode Research and Development tahap awal yaitu menemukan potensi dan masalah, studi literatur, mengkaji data informasi, penyusunan desain produk dan melakukan uji ahli tahap satu. Uji ahli tahap I melibatkan ahli bidang olahraga, ahli bidang olahraga rekreasi Paser, ahli bidang Pariwisata dan ahli kebahasaan. Teknik pengumpulan data yang dilakukan yaitu studi lapangan, wawancara dan studi pustaka. Hasil dari penelitian ini yaitu hasil uji ahli bidang olahraga memperoleh skor rata-rata 2 dengan kesimpulan dapat digunakan dengan banyak perbaikan. Hasil uji ahli bidang olaraga rekreasi Paser memperoleh skor ratarata 4 dengan kesimpulan dapat digunakan dengan sedikit perbaikan. Hasil uji ahli bidang pariwisata memperoleh skor rata-rata 3 dengan kesimpulan dapat digunakan dengan sedikit perbaikan. Hasil uji ahli bidang kebahasaan memperoleh skor rata-rata 4 dengan kesimpulan dapat digunakan dengan sedikit perbaikan. Kesimpulan pada penelitian ini yaitu produk yang dihasilkan dapat digunakan dengan sedikit perbaikan. Saran bagi penelitian selanjutnya diharapkan dapat melakukan tahap evaluasi responden secara langsung guna menyebarluaskan informasi tentang olahraga paser.
\end{abstract}

Kata Kunci: Olahraga Rekreasi, Paser, Pariwisata Olahraga

\begin{abstract}
The Cacaban Reservoir Tourism Object has potential that can be developed, the lack of visitor interest in the Cacaban Reservoir is the main problem. The purpose of this study is to develop the potential of Paser recreational sports as a new attraction in the Cacaban to increase visitor interest. This study uses the Research and Development method in the early stages of finding potentials and problems, studying literature, reviewing information data, preparing product designs and conducting stage one expert tests. The expert test phase I involves experts in the field of sports, experts in the field of recreational sports in Paser, experts in tourism and linguistic experts. Data collection techniques used are field studies, interviews and literature studies. The results of this study are the results of the expert test in the field of sports obtaining an average score of 2 with the conclusion that it can be used with many improvements. The conclusion in this study is that the resulting product can be used with a little improvement. Suggestions for further research are expected to be able to conduct a direct evaluation of respondents in order to disseminate information about paser recreational sports.
\end{abstract}

Keywords: Recreational Sports, Paser, Sports Tourism

Dipublikasikan Oleh :

UPT Publikasi dan Pengelolaan Jurnal

Universitas Islam Kalimantan Muhammad Arsyad Al-Banjari Banjarmasin 


\section{PENDAHULUAN}

Pariwisata menjadi salah satu fokus dari berbagai macam negara di dunia karena dapat digunakan sebagai sektor yang mendorong perekonomian nasional (Bahiyah et al., 2018). Salah satu upaya mengingkatkan pembangunan dan perekonomian melalui pariwisata yaitu dengan cara memanfaatkan sektor sumber daya alam serta kearifan lokal. Pariwisata telah menjadi bagian kehidupan bagi masyarakat menengah masa kini, pariwisata sudah menjadi suatu konsep dalam kehidupan masyarakat dari yang hanya untuk melepas penat, maupun untuk mata pencaharian hingga gaya hidup(Sanusi, 2020). Selain pemanfaatan dari sektor ekonomi dan pembangunan, pariwisata juga telah menjadi suatu kebutuhan yang tidak boleh diabaikan oleh manusia (Muktiaj, 2013).

Sport Tourism telah menjadi industri pariwisata dengan perkembangan yang sangat signifikan di seluruh dunia (Masjhoer, 2020). Ada banyak keuntungan olahraga pariwisata yang didapatkan diantaranya: 1) Dapat menciptakan pekerjaan dan pendapatan, 2) Mendatangkan keuntungan bagi perusahaan lokal, 3) Menambah pajak pendapatan, 4) Dapat menaikkan jumlah investasi dalam infrastruktur dan fasilitas olahraga (Lupikawaty et al., 2013). Selain itu, dampak positif pariwisata olahraga juga lebih signifkan dibandingkan dampak negatif yang didapatkan baik dari segi lingkungan ataupun sosial bagi penduduk lokal (Ivanov \& Ivanova, 2012).

Perkembangan pariwisata di Kabupaten Tegal semakin pesat dalam beberapa dekade terakhir. Selain potensi sumber daya alam yang melimpah, keberadaan penduduk setempat juga memiliki peran penting dalam menunjang kemajuan pariwisata, bukan hanya mengembangkan parwisata daerah penduduk juga berperan dalam mengurangi angka pengangguran (Muktiaj, 2013). Ada banyak potensi wisata melimpah di Kabupaten Tegal seperti Objek Wisata Guci, Pantai Purwahamba Indah, Wisata Waduk Cacaban serta masih banyak yang lainnya. Waduk dapat difungsikan sebagai tempat rekresasi maupun kawasan (Sumargo, 2008). Waduk Cacaban memiliki banyak potensi yang dapat dikembangkan melalui olahrga pariwisata yang bisa menjadi daya tarik maupun ciri khas untuk meningkatkan kunjungan wisata.

Permasalahan yang ada di Objek Wisata Waduk cacaban yaitu kurangnya minat pengunjung Objek Wisata Waduk Cacaban dikarenakan belum adanya ciri khas khusus yang menjadi daya tarik dibandingkan Objek Wisata lain yang berada di Kabupaten Tegal seperti Guci yang memiliki ciri khas tersendiri yaitu pemandian air panasnya. Untuk meningkatkan minat pengunjung dan mengembangkan potensi olahraga memerlukan penyediaan sarana dan prasarana serta pembangunan infrastuktur yang baik untuk menunjang peningkatan daya tarik wisatawan (Mustikawati et al., 2017).

Alam berperan sebagai sumber daya kegiatan wisata yang sangat besar dan penting karena alam menjadi daya tarik yang utama untuk meningkatkan kunjungan wisata (Suparwoko, 2015). Pengembangan wisata di Waduk Cacaban menjadi suatu hal penting karena diharapkan dapat mengembengkan potensi sumber daya alam serta membuat daya tarik baru untuk menarik minat pengunjung. Sumber daya yang melimpah di Waduk Cacaban dapat dimanfaatkan untuk kehidupan sehari - hari maupun untuk peningkatan perekonomian masyarakat sekitar atau hanya sekedar hobi untuk mengisi keseharian dengan berbagai cara yang mereka melakukan untuk memanfaatan sumber daya alam, salah satunya melalui olahraga paser (Paser Mania Tegal, 2020).

Olahraga paser ini muncul dari kejenuhan beberapa komunitas seperti para pemburu, atlet ,menembak, pemancing, serta beberapa komunitas lain. Semakin berkurangnya habitat hewan buruan yang ada di darat karena banyak satwa yang dilindungi menjadi salah satu alasan para pemaser (pegiat olahraga paser) melakukan olahraga ini serta melimpahnya ikan di Waduk Cacaban menjadi salah satu potensi yang dimanfaatkan para pemaser. Ikan memiliki kandungan zat gizi tinggi seperti protein, lemak, vitamin - vitamin, mineral, karbohidrat, serta kadar air yang baik (Firlianty \& Pratasik, 2018). Selain itu, ikan memiliki nilai ekonomis yang tinggi dibandingkan hewan yang selama ini menjadi buruan di darat. Untuk menekan perburuan ilegal para pemburu mengalihkan buruan mereka ke ikan khususnya ikan toman. Ikan toman sendiri menjadi salah satu predator yang bisa memakan semua hewan yang bisa ditelan, ikan berukuran kecil dan satwa lain yang berada di permukaan air. Hewan ini menempati puncak piramida rantai makanan ekosistem perairan air tawar sehingga ikan lain bisa musnah. (Paser Mania Tegal, 2020). Namun, ikan Toman memiliki kandungan albumin yang dapat digunakan dalam ilmu kedokteran untuk pemulihan jaringan tubuh yang terbelah atau telah mengalami kerusakan (Fitriyani, 2018),

Berdasarkan latar belakang di atas peneliti tertarik untuk melakukan penelitian tentang Pengembangan Potensi Olahraga Rekreasi Paser (Tahap Awal) Sebagai Daya Tarik Baru di Objek Wisata Waduk Cacaban Kabupaten Tegal.

Dipublikasikan Oleh : 


\section{METODE}

Penelitian ini merupakan penelitian payung yang menggunakan metode Research and Development (RnD) dengan urutan tahapan penilitian ini dibagi menjadi tiga tahapan besar, terdiri dari beberapa prosedur pelaksanaan yaitu 1) Tahap awal (desain produk dan tahap uji Ahli pertama) merupakan tahap yang dilakukan oleh penelitil 2) Tahap lanjutan (masukan hasil uji ahli pertama, revisi, masukan kedua) dilakukan oleh rekan peneliti yaitu Nur Hadziq Haidar, dan 3) Tahap akhir (masukan hasil ahli kedua, revisi, produk akhir) yang dilakukan oleh rekan peneliti Dzulfikri Ritonga. Dalam pengembangan ini menggunakan model pengembangan prosedural yang dimodifikasi untuk kebutuhan penelitian. Tahapan ada tahap awal ini yaitu menemukan potensi dan masalah, studi literature, mengkaji informasi, menyusun desain produk, dan melakukan uji ahli tahap I. Uji ahli tahap I melibatkan beberapa ahli diantaranya ahli bidang olahraga, ahli bidang olahraga rekreasi Paser, ahli bidang Pariwisata dan ahli kebahasaan. Teknik pengumpulan data yang dilakukan yaitu studi lapangan, wawancara dan studi pustaka. Analasis data menggunakan analaisis

\section{HASIL DAN PEMBAHASAN}

\section{Hasil Uji Ahli Olahraga}

Uji ahli bidang oahraga dilakukan oleh Gustiana Mega Anggita selaku Dosen Jurusan Ilmu Keolahragaan Universitas Negeri Semarang pada Selasa 13 Juli 2021. Uji ahli manajemen olahraga dilakukan dengan tujuan untuk mendapatkan komentar saran serta mengetahui kekurangan dari produk buku olahraga rekreasi paser dari segi olahraga secara umum. Adapun input hasil uji ahli olahraga dapat dilihat pada tabel di bawah ini.

\section{Tabel Input Hasil Uji Ahli Olahraga}

\begin{tabular}{|c|l|}
\hline No. & Saran dan Komentar \\
\hline 1. & $\begin{array}{l}\text { Buku sebenarnya dapat dikembangkan lagi lebih detail tentang olahraga rekreasi paser. } \\
\text { Lebih baik didalam buku dihantarkan untuk memahami terlebih dahulu apa itu olahraga } \\
\text { paser, lebih ke araf define secara esensi paser itu apa supaya orang awam dapat } \\
\text { memahami apa yang dimaksud }\end{array}$ \\
\hline 2. & $\begin{array}{l}\text { Di Bab komponen kondisi fisik lebih baik kondisi fisik dominan padaolahraga paser } \\
\text { diberikan nomor }\end{array}$ \\
\hline 3. & $\begin{array}{l}\text { Perlu ada bab atau sub bab teknis pelaksanaan untuk melakukan } \\
\text { olahraga paser seperti aturan permainan atau perlombaan maupun kompetisi }\end{array}$ \\
\hline 4. & $\begin{array}{l}\text { Sarana dan prasarana juga bisa dijelaskan lebih detail lagi jika terdapat informasi } \\
\text { karakteristik sungai atau waduk atau danau yang sesuai untuk digunakan olahraga ini. } \\
\text { Sepertinya ini juga termasuk olahraga ekstrim, ada pelampung juga yang digunakan, } \\
\text { jika ada standard ala tyg harus dimiliki lebih baik diinformasikan dalam buku, misalnya } \\
\text { olahraga softball, bat yang digunakan harus ada sertifikat atau label dari ISF. }\end{array}$ \\
\hline
\end{tabular}

Saran dan komentar yang didapatkan dari ahli olahraga dapat disimpulkan bahwa produk penelitian dan pengembangan dapat digunakan dengan banyak perbaikan yang mana selanjutnya akan dilakukan revisi pada tahapan lanjutan yang dilakukan oleh rekan peneliti.

\section{Hasil Uji Ahli Olahraga Paser}

Desain produk buku pedoman olahraga rekreasi paser yang telah dikembangkan diuji terlebih dahulu oleh ahli olahraga rekreasi paser. Uji ahli olahraga rekreasi paser dilaksanakan oleh Sekertaris Persatuan Pemaser Ikan Indonesia (PPII) Christian Ardita pada hari Jumat 09 Juli 2021 yang mempunyai latar belakang sesuai dengan materi yang dikembangkan. Uji ahli olahraga rekreasi paser bertujuan untuk mendapatkan informasi tambahan,

Dipublikasikan Oleh : 
komentar dan saran agar buku pedoman olahraga rekreasi paser yang dikembangkan menjadi produk yang berkualitas secara aspek dan materi. Input hasil uji ahli tersebut dapat dilihat pada tabel dibawah ini.

Tabel Input Uji Ahli Olahraga Paser

\begin{tabular}{|c|l|}
\hline No. & Saran dan Komentar \\
\hline 1. & $\begin{array}{l}\text { Penekanan untuk tujuan sosial kemasyarakatan yang dapat lebih dijabarkan kembali, } \\
\text { seperti kegiatan sosial dan bakti sosial. Sehingga masyarakat akan lebih memahami } \\
\text { serta merasakan kehadiranpemaser yang tergabung dalam wadah Persatuan Pemaser } \\
\text { Ikan Indonesia }\end{array}$ \\
\hline 2. & $\begin{array}{l}\text { Penekanan tujuan dan sasaran untuk mengurangi atau mengalihkan para pemburu } \\
\text { darat yang dalam hal ini buruannya sudah semakin jarang serta sudah banyak yang } \\
\text { dilindungi untuk beralih menjadi pemaser dengan hewan buruan ikan yang masih } \\
\text { melimpah dan kebanyakan dapat dikonsumsi oleh seluruh keluarga dibandingkan } \\
\text { dengan hasil buruan darat }\end{array}$ \\
\hline
\end{tabular}

Saran dan komentar yang didapatkan dari ahli olahraga rekreasi paser dapat disimpulkan bahwa produk penelitian dan pengembangan dapat digunakan dengan sedikit perbaikan yang mana selanjutnya akan dilakukan revisi pada tahapan lanjutan yang dilakukan oleh rekan peneliti.

\section{Hasil Uji Ahli Pariwisata}

Uji Ahli Pariwisata dilaksanakan oleh Ahmad Abdul Khasib selaku Ketua UPTD Pengelolaan Obyek Wisata Dinas Pemuda Olaraga dan Pariwisata Kabupaten Tegal pada hari Jumat 09 Juli 2021. Tujuan dilakukan uji ahli pariwisata yaitu untuk mendapatkan komentar dan saran serta informasi tambahan terkait bidang pariwisata yang berkaitan dengan olahraga rekreasi paser, adapun input hasil uji ahli bidang pariwisata yaitu:

Tabel Input Uji Ahli Bidang Pariwisata

\begin{tabular}{|c|l|}
\hline No. & Saran dan Komentar \\
\hline 1. & $\begin{array}{l}\text { Eksplorasi potensi alam sebagai unsur dasar yang melatarbelakangi berdirinya } \\
\text { olahraga paser ikan perlu pendalaman secara intensif dan komperhensif dipadukan } \\
\text { dengan prinsip-prinsip dasar pariwisata (Attraction, Aksebilitas dan Amenitas) agar } \\
\text { berbanding lurus dengan esensi dari olahraga rekreasi }\end{array}$ \\
\hline 2. & $\begin{array}{l}\text { Struktur dan mekanisme perlombaan dipertajam kembali seperti scoring, kategori } \\
\text { dan aturan perlombaan lainnya }\end{array}$ \\
\hline 3. & $\begin{array}{l}\text { Belum adanya penjelasan secara empiris baik laboratoris maupun fakta di lapangan } \\
\text { terkait dengan keamanan dan kenyamanan senapan angina (alat paser ikan) }\end{array}$ \\
\hline
\end{tabular}

Saran dan komentar yang didapatkan dari ahli olahraga bidang pariwisata dapat disimpulkan bahwa produk penelitian dan pengembangan dapat digunakan dengan sedikit perbaikan yang mana selanjutnya akan dilakukan revisi pada tahapan lanjutan yang dilakukan oleh rekan peneliti.

Hasil Uji Ahli Kebahasaan

Uji ahli kebahasaan dilaksanakan oleh Riyadi Widhiyanto selaku guru Bahasa Indonesia SMP Negeri 01 Ungaran pada hari Minggu 18 Juli 2021. Tujuan dilakukannya uji kebahasaan yaitu untuk mendapatkan saran dan komentar terkait Bahasa yang digunakan dalam produk penelitian dan pengembangan. Adapun input hasil uji ahli kebahasaan dapat dilihat pada tabel berikut.

Tabel Input Hasil Uji Ahli Kebahasaan

\begin{tabular}{|l|l|}
\hline No. & Saran dan Komentar \\
\hline 1. & $\begin{array}{l}\text { Perlu dilengkapi lagi beberapa bagian buku yang belum ada seperti petunjuk } \\
\text { penggunaan buku dan rangkuman (jika memang ada) }\end{array}$ \\
\hline
\end{tabular}

Saran dan komentar yang didapatkan dari ahli kebahasaan dapat disimpulkan bahwa produk penelitian dan pengembangan dapat digunakan dengan sedikit perbaikan yang mana selanjutnya akan dilakukan revisi pada tahapan lanjutan yang dilakukan oleh rekan peneliti.

\section{Pembahasan}

Produk buku olahraga rekreasi Paser layak dan baik digunakan apabila dalam proses pengembangannya, mendapatkan hasil uji tim ahli menunjukkan kategori "layak" digunakan. Hasil uji ahli bidang olahraga tahap I memperoleh skor rata- rata 2 "cukup layak" dengan kesimpulan dapat digunakan dengan banyak perbaikan.

Dipublikasikan Oleh : 
Hasil uji ahli bidang olaraga rekreasi Paser tahap I memperoleh skor rata-rata 4 "sangat layak" dengan kesimpulan dapat digunakan dengan sedikit perbaikan. Hasil uji ahli bidang pariwisata tahap I memperoleh skor rata-rata 3 "layak" dengan kesimpulan dapat digunakan dengan sedikit perbaikan. Hasil uji ahli bidang kebahasaan tahap I memperoleh skor rata-rata 4 "sangat layak" dengan kesimpulan dapat digunakan dengan sedikit perbaikan..

Berdasarkan hasil perolehan skor uji ahli tahap I dari bidang olahraga, bidang olahraga rekreasi paser, bidang pariwisata dan bidang kebahasaan dapat disimpulkan bahwa skor rata rata 3,2 yang termasuk dalam kategori "Layak digunakan dengan sedikit perbaikan". Tahapan selanjutnya adalah merevisi masukan dan saran dari validator serta melakukan uji ahli tahap kedua yang dilakukan oleh rekan peneliti Nur Hadziq Haidar serta tahapan akhir yaitu melakukan revisi produk kedua dan finalisasi produk yang dilakukan oleh rekan peneliti Dzulfikri Ritonga.

\section{PENUTUP}

Kesimpulan pada penelitian ini yaitu pengembangan olahraga rekreasi paser memiliki potensi menjadi daya tarik baru yang ada di Objek Wisata Waduk Cacaban Kabupaten Tegal. Potensi tersebut dijabarkan melalui sejarah, pengembangan dan sarana prasarana olahraga rekreasi paser yang berkaitan dengan kondisi alam yang ada di Waduk Cacaban. Olahraga rekreasi paser juga sudah memiliki badan hukum dan berada di bawah naungan Komite Olahraga Rekreasi Masyarakat Indonesia (KORMI). Selain itu, olahraga ini bisa dijadikan event yang dapat meningkatkan pendapatan masyarakat maupun pemerintah setempat. Tidak hanya dari event, olahraga ini dapat dijadikan suatu wahana objek wisata baru di Waduk Cacaban yang bisa membuka lapangan pekerjaan untuk masyarakat sekitar.

Adapun saran yang perlu diperhatikan diantaranya:

Bagi Paser Mania Tegal

Dapat dijadikan penunjang serta informasi dalam melakukan kegiatan olahraga rekreasi Paser dan dapat menjadi masukan dalam penyelenggaraan event maupun pengembangan paser sebagai rekreasi.

Bagi Disporapar Kabupaten Tegal

Dapat mendukung serta memfasilitasi diadakanya kegiatan olahraga rekreasi Paser di Objek Wisata Waduk Cacaban sebagai destinasi wisata baru serta menjadi acuan untk penyelenggaraan event resmi yang berada dibawah naungan bidang pariwisata Disporapar Kabupaten Tegal.

Bagi Penelitian Selanjutnya

Ada beberapa saran yang perlu diperhatikan bagi peneliti selanjutnya yaitu:

Peneliti selanjutnya diharapkan dapat mengkaji lebih banyak sumber referensi terkait olahraga rekreasi Paser agar hasil yang dicapai lebih maksimal.

Peneliti selanjutnya diharapkan dapat melakukan tahap evaluasi responden secara langsung kepada para pegiat olahraga rekreasi paser dan masyarakat guna menyebarluaskan informasi tentang olahraga rekreasi Paser.

\section{REFERENSI}

Bahiyah, C., R, W. H., \& Sudarti. (2018). Strategi Pengembangan Potensi Pariwisata di Pantai Duta Kabupaten Probolinggo. Jurnal Ilmu Ekonomi, 2(1), 95-103. http://ejournal.umm.ac.id/index.php/jie/article/view/6970.

Firlianty, F., \& Pratasik, S. B. (2018). Potensi Puding Ikan Toman (Channa Micropeltes) dan Ikan Gabus (Channa Striata) untuk Percepatan Penyembuhan pada Hewan Uji Tikus. Agrikan: Jurnal Agribisnis Perikanan, 11(2), 65. https://doi.org/10.29239/j.agrikan.11.2.65-69

Fitriyani, E. (2018). The Effect of Temperature and Time of Extraction Toman Fish (Channa micropeltes) become to Albumin Powder. Jurnal Galung Tropika, 7(2), 102-114.

Ivanov, S., \& Ivanova, M. G. (2012). Triple Bottom Line Analysis of Potential Sport Tourism Impacts on Local Communities - a Review. SSRN Electronic Journal, 1-11. https://doi.org/10.2139/ssrn.1923104

Lupikawaty, M., Wilianto, H., \& Sriwijaya, P. N. (2013). Potensi Sport Tourism Di Kota Palembang : Perspektif Ekonomi. Jenius, 3(2), 128-136.

Masjhoer, J. M. (2020). Model Pengembangan International Musi Triboatton sebagai Atraksi Sport Tourism. Jurnal Pariwisata Terapan, 3(2), 154. https://doi.org/10.22146/jpt.41807

Muktiaj, A. (2013). KONTRIBUSI TINGKAT PENDIDIKAN PENDUDUK TERHADAP AKTIVITAS PEREKONOMIAN DI OBYEK WISATA WADUK CACABAN KECAMATAN KEDUNGBANTENG KABUPATEN TEGAL. In Journalpendidikan Olahraga. https://doi.org/10.1088/1751-8113/44/8/085201

Dipublikasikan Oleh :

UPT Publikasi dan Pengelolaan Jurnal

Universitas Islam Kalimantan Muhammad Arsyad Al-Banjari Banjarmasin 
Mustikawati, T. A., Pangestuti, E., \& Sunarti. (2017). Analisis pengembangan sarana prasarana obyek wisata alam telaga ngebel dalam meningkatkan kesejahteraan ekonomi masyarakat. Jurnal Administrasi Bisnis, $53(2), 1-10$.

Sanusi, R. (2020). Analisis Potensi Pariwisata Olahraga Berbasis Sumber Daya Alam Di Kab. Karimun Provinsi Kep. Riau. Jurnal Ilmu Keolahragaan, 3(1), 1. https://doi.org/10.26418/jilo.v3i1.34999

Sumargo, Ag. (2008). Oleh : PROGRAM PASCASARJANA MAGISTER TEKNIK PEMBANGUNAN WILAYAH DAN KOTA.

Suparwoko. (2015). Analisis Sumber Daya Sungai Code Sebagai Basis Wisata Alam di Kawasan Perkotaan Yogyakarta. Universitas Islam Indonesia, June 2010.

Dipublikasikan Oleh : 